\title{
Effect of lycopene on cell viability and cell cycle progression in human cancer cell lines
}

\author{
Anderson Junger Teodoro ${ }^{1,4 *}$, Felipe Leite Oliveira², Nathalia Balthazar Martins², Guilherme de Azevedo Maia ${ }^{2}$, \\ Renata Brum Martucci ${ }^{2}$ and Radovan Borojevic ${ }^{3}$
}

\begin{abstract}
Background: Lycopene, a major carotenoid component of tomato, has a potential anticancer activity in many types of cancer. Epidemiological and clinical trials rarely provide evidence for mechanisms of the compound's action, and studies on its effect on cancer of different cell origins are now being done. The aim of the present study was to determine the effect of lycopene on cell cycle and cell viability in eight human cancer cell lines.

Methods: Human cell lines were treated with lycopene $(1-5 \mu \mathrm{M})$ for 48 and $96 \mathrm{~h}$. Cell viability was monitored using the method of MTT. The cell cycle was analyzed by flow cytometry, and apoptotic cells were identified by terminal deoxynucleotidyl transferase-mediated dUTP nick labeling (TUNEL) and by DAPI.

Results: Our data showed a significant decrease in the number of viable cells in three cancer cells lines (HT-29, T84 and MCF-7) after $48 \mathrm{~h}$ treatment with lycopene, and changes in the fraction of cells retained in different cell cycle phases. Lycopene promoted also cell cycle arrest followed by decreased cell viability in majority of cell lines after $96 \mathrm{~h}$, as compared to controls. Furthermore, an increase in apoptosis was observed in four cell lines (T-84, HT-29, MCF-7 and DU145) when cells were treated with lycopene.

Conclusions: Our findings show the capacity of lycopene to inhibit cell proliferation, arrest cell cycle in different phases and increase apoptosis, mainly in breast, colon and prostate lines after $96 \mathrm{~h}$. These observations suggest that lycopene may alter cell cycle regulatory proteins depending on the type of cancer and the dose of lycopene administration. Taken together, these data indicated that the antiproliferative effect of lycopene was cellular type, time and dose-dependent.
\end{abstract}

Keywords: Lycopene, Cancer, Bioactive compounds, Cell cycle

\section{Background}

Diets high in fruits and vegetables are associated with reduced rates of cancer and coronary heart disease. Lycopene, a major carotenoid component of tomato, exhibited potential anticancer activity in many types of cancer $[1,2]$. Epidemiological studies reported statistically significant inverse association between tomato consumption and risk of several types of cancer such as lung, prostate and colon cancer [3-5].

\footnotetext{
*Correspondence: atteodoro@gmail.com

'Laboratory of Nutritional Biochemistry, Program of Food and Nutrition, UNIRIO, Rio de Janeiro, Brazil

${ }^{4}$ Departamento de Tecnologia de Alimentos, Universidade Federal do Estado do Rio de Janeiro, Escola de Nutrição, CEP 22290-240 Rio de Janeiro, RJ, Brazil

Full list of author information is available at the end of the article
}

Despite epidemiological and small clinical trial evidence suggesting a possible protective effect of lycopene, the mechanism of its action including cell cycle arrest and induction of apoptosis, remain poorly understood $[6,7]$. Lycopene has been proposed to negatively affect cancer cells or development of cancer by modulating cell cycle progression and cell proliferation. It has an inhibitory effect on DNA synthesis, initiating up-regulation of gap-junction proteins and a reduction of local androgen signaling, impact IGIF-1 signaling, antioxidant activity and induction of apoptotic cell death, indicating that carotenoids are promising chemopreventive agents, with several cellular effects which are both genomic and nongenomic. [8,9]. Although there is significant evidence supporting the action of lycopene as a potent antioxidant, a number of other potential mechanisms through

\section{Biomed Central}


which tomato products providing lycopene may reduce the risk for cancer can be proposed [10-12].

Lycopene has antiproliferative effect on prostate and breast cancer cell lines. In breast cancer models, reduced expression of cell cycle regulatory proteins, such as cyclins D1 and E and the cyclin-dependent kinases 2 and 4, as well as suppression of insulin-like growth factor (IGF-I) action have been correlated with lycopene's effects on proliferation [13,14]. Other studies reported that lycopene had limited effect on cell proliferation of cancerous and noncancerous cell lines in an in vitro system with doses within the physiological range, but only rare studies reported no effect of lycopene on cell proliferation [15].

Deregulated cell cycle is one of the major hallmarks of cancer cells. These cells may lose the ability to regulate the cell cycle and control their rate of proliferation. A rate-limiting step in the cell cycle that is often disturbed in cancer is the progression of cells through the first gap (G1) phase [16]. Recently, several reports show that lycopene can induce cell cycle arrest at the G1 phase. Park et al. [17] reported that the growth of human hepatoma cells (Hep3B) was inhibited $20-50 \%$ by lycopene at physiological concentrations as low as $0.2 \mu \mathrm{M}$. Lycopene was found to induce G0/G1 arrest and S phase block. In a similar study with the human prostate cancer cell lines LNCaP and PC3, Ivanov et al. [18] found that lycopene induced mitotic arrest at the G0/G1 phase.

Although, the role of lycopene in prevention of prostate cancer has been studied more extensively, human studies with tomatoes and lycopene on cancer affecting other organs are now being undertaken. The majority of studies on cell cycle were carried out in prostate and breast cancer cell lines after $48 \mathrm{~h}$ of lycopene treatment. The aim of the present study was to determine the effect of lycopene on cell cycle and cell proliferation in eight different human cancer cell lines at different time points.

\section{Results}

Effect of lycopene on number of viable cells in culture

All cells lines were shown to have normal growth characteristics expected under standard in vitro culture conditions. Previous studies reported that lycopene formulated as $10 \%$ WS granules was not toxic. Hereafter, all the results refer to lycopene with this vehicle, already used in our previous studies in vitro [19].

The plating of cancer cells lines was followed by $24 \mathrm{~h}$ recovery, and cell were subsequently incubated with 1,3 or $5 \mu \mathrm{M}$ lycopene during 24, 48 and $96 \mathrm{~h}$. Lycopene was internalized into all cell lines, and reached the highest intracellular concentrations in HT-29 and T-84 lines. We tested the effect of lycopene on viability of the same cell lines in higher concentrations, but the results showed the same characteristics of inhibition from 5 to 40 micromolar. The mean intracellular lycopene concentration was $0.2-1.5 \mathrm{fmol} / \mathrm{L}$, no increase was observed from 24 to $48 \mathrm{~h}$, and only a slight increase was noted after 96 hours (data not shown).

We used the MTT assay to monitor the cell viability. After treatment for $48 \mathrm{~h}$, a significant decrease in the number of viable cells was observed in three cancer cells lines as compared to controls, reaching $30 \%$ reduction in HT-29 and T84 cells and 10\% in MCF-7 cells. A discreet effect was observed in DU 145 and HeLa cells only with $5 \mu \mathrm{M}$ lycopene. No effect was seen in the other cells (Figure 1).

After 96 h, lycopene caused a significant modification of cell viability in six out of eight cell lines. Lycopene treatment inhibited in $25 \%$ and $30 \%$ cell viability of MCF-7 and HepG2 cells, respectively. The lowest cell viability reduction was observed in Hela and Hep-2 cells

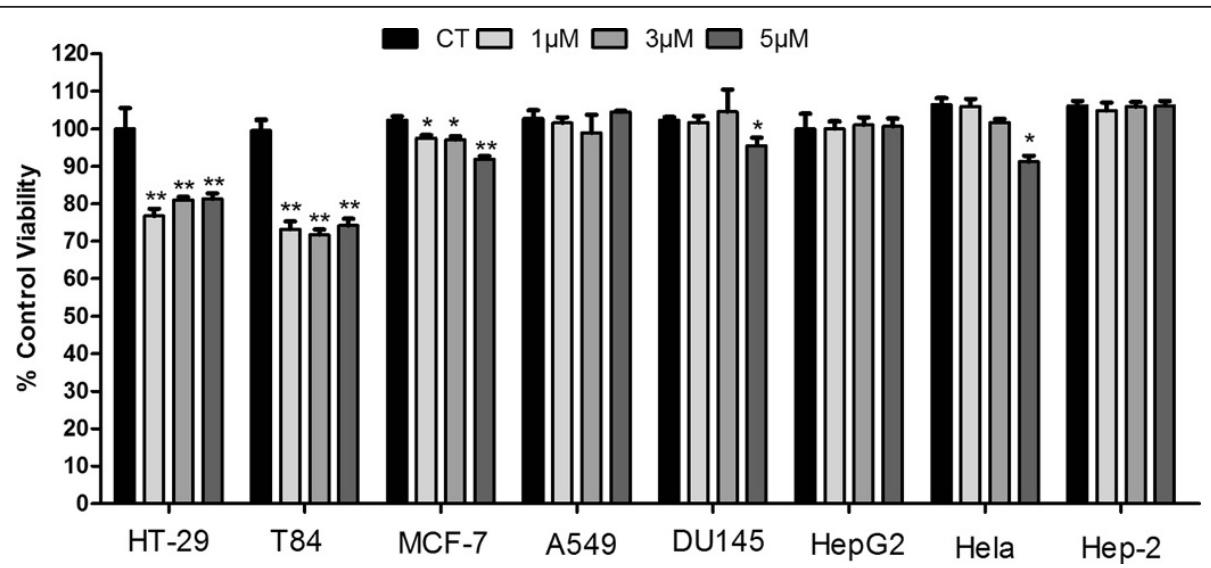

Figure $\mathbf{1}$ Effect of lycopene on cell lines viability after $\mathbf{4 8} \mathbf{~} \mathbf{~ o f}$ exposure using $\mathbf{M T T}$ assays. The representative experiment is a mean \pm error standard and a significant difference between each lycopene concentration and the control evaluated using the Tukey-Kramer Multiple Comparison test, ${ }^{*} p<0.05 ;{ }^{* *} p<0.01$. 


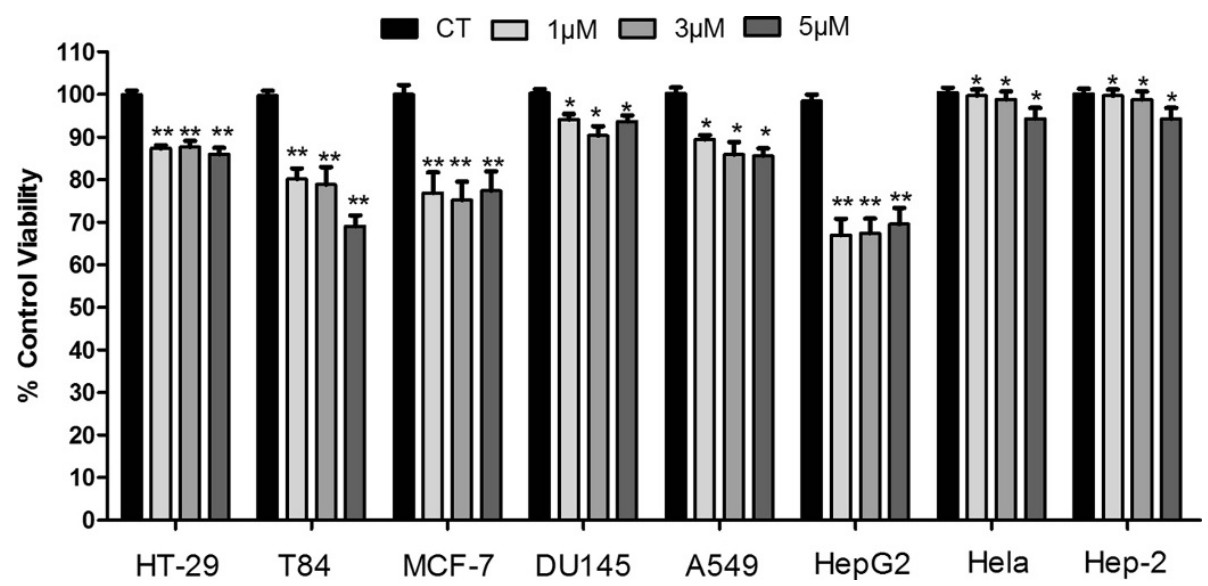

Figure 2 Effect of lycopene on cell lines viability after $96 \mathrm{~h}$ of exposure using MTT assays. The representative experiment is a mean \pm error standard and a significant difference between each lycopene concentration and the control evaluated using the Tukey-Kramer Multiple Comparison test; ${ }^{*} p<0.05 ;{ }^{* *} p<0.01$

(Figure 2). Taken together, these data indicate that the effect of lycopene was cell-specific and time dependent, and that this effect required a relatively long incubation time in the majority of cell lines.

\section{Effect of lycopene on cell cycle progression}

In order to monitor the influence of lycopene on cell cycle, we treated cells with lycopene for 48 and $96 \mathrm{~h}$ and quantified the percentage of cells in different cell cycle phases (Tables 1 and 2).

After $48 \mathrm{~h}$, the three cell lines that have undergone major changes in cell viability were also those that had major changes in the percentages of cells in different cell cycle phases. In HT-29 cells, lycopene induced an increase in the percentage of cells in G0/G1. At $5 \mu \mathrm{M}$, a small inhibition of cell cycle progression was also observed in T84 cells, followed by decreased cell numbers in $\mathrm{G} 2 / \mathrm{M}$ phase $(\mathrm{p}<0.05)$. Moreover, treatment with lycopene ( 3 and $5 \mu \mathrm{M}$ ) for $48 \mathrm{~h}$ in MCF-7 cells resulted in G0/G1 arrest, showed by the accumulation of cells in G0/G1 with concomitant decrease in in the G2/M phase $(\mathrm{p}<0.05)$ (Table 1).

A549 and DU145 lines showed minor changes in the distribution profile in cell cycle phases, with an increase of cells in G0/G1 phase and a decrease in G2/M phase (Table 1$)$, only with the highest dose of lycopene $(5 \mu \mathrm{M})$ $(\mathrm{p}<0.05)$. No change was observed after exposure to lycopene in Hep-2, HeLa and HepG2 lines (Table 1), confirming the results of cell viability (Figure 1).

After $96 \mathrm{~h}$, significant changes were observed in cell cycle of cancer cells treated with lycopene as compared to controls (Table 2). HT-29 cells presented an increase in $\mathrm{G} 2 / \mathrm{M}$ phase when treated with 3 and $5 \mu \mathrm{M}$ lycopene, with a decrease in the G0/G1 phase $(\mathrm{p}<0.05)$. Lycopene also caused T84 cells to accumulate in the G0/G1 phase, regardless of the dose. Treatment with 1 and $5 \mu \mathrm{M}$ lycopene led to an increase in the percentage of cells in G2/ $\mathrm{M}$ phase.

In MCF-7 cells, an increase of cells in G0/G1 phase and a decrease in $\mathrm{G} 2 / \mathrm{M}$ phase were observed after $48 \mathrm{~h}$ treatment with lycopene $(\mathrm{p}<0.05)$. A549 cells showed a small increase of cells in $G 2 / M$ phase $(\mathrm{p}<0.05)$, with no significant difference among the different concentrations of lycopene.

The DU145 cell line showed an increase in cells retained in the G2/M phase, followed by a decrease of cells in G0/G1 phase when treated with 3 and $5 \mu \mathrm{M}$ of lycopene $(p<0.01)$. This same was observed in Hep-G2 line at all concentrations, being more pronounced with higher concentrations $(3-5 \mu \mathrm{M})$ of lycopene, coupled with a decrease in the percentage of cells in the phase $S$ $(\mathrm{p}<0.05)$. Similar to the data on cell viability, lycopene did not change the growth profile of two cell lines (Hela and Hep-2) $(\mathrm{p}>0.05)$.

\section{Apoptosis}

Quantification of apoptosis can be a useful measure of cancer cell kinetics. Alteration of the balance between proliferation and apoptosis is associated with cancer. The cancer cell lines were incubated with lycopene $(3 \mu \mathrm{M})$ for $96 \mathrm{~h}$. An increase in apoptosis was observed in four cell lines (T-84, HT-29, MCF-7 and DU145) treated with lycopene (Figure 3A). Most cancer cell lines that showed an increased number of cells in $\mathrm{G} 2 / \mathrm{M}$ phase after treatment with lycopene for 96 hours (HT29 and DU145), were also the ones with increased apoptosis (3.5 and 4 fold, respectively). This was not the case of HepG2 cells (Table 2) and cell specific differences in this regard should be studied further. In addition, lycopene increased 2-fold apoptosis in MCF-7 and T84 cells 
Table 1 Effect of lycopene (1-5 $\mu \mathrm{M}$ ) on cell cycle progression in different human cancer cell lines after 48 hours

\begin{tabular}{|c|c|c|c|c|c|}
\hline Cell Lines & Cell Cyle phases & CT & $1 \mu \mathrm{M}$ & $3 \mu \mathrm{M}$ & $5 \mu \mathrm{M}$ \\
\hline \multirow[t]{3}{*}{ HT-29 } & G0/G1 & $47.40 \pm 0.57$ & $61.65 \pm 3.61^{*}$ & $55.10 \pm 1.41^{*}$ & $59.05 \pm 7.42^{*}$ \\
\hline & $\mathrm{s}$ & $21.30 \pm 4.53$ & $19.70 \pm 0.42$ & $19.75 \pm 0.49$ & $20.70 \pm 0.85$ \\
\hline & G2/M & $18.55 \pm 3.61$ & $13.70 \pm 1.84$ & $18.90 \pm 0.42$ & $12.45 \pm 3.18$ \\
\hline \multirow[t]{3}{*}{ T84 } & G0/G1 & $42.20 \pm 0.39$ & $40.31 \pm 0.40$ & $41.10 \pm 0.71$ & $44.96 \pm 2.76^{*}$ \\
\hline & $S$ & $10.93 \pm 0.13$ & $11.90 \pm 0.60$ & $10.25 \pm 1.07$ & $10.60 \pm 0.45$ \\
\hline & G2/M & $33.00 \pm 0.09$ & $35.03 \pm 1.74$ & $33.90 \pm 0.88$ & $31.53 \pm 0.81^{*}$ \\
\hline \multirow[t]{3}{*}{ MCF-7 } & G0/G1 & $29.45 \pm 2.05$ & $29.15 \pm 1.48$ & $32.65 \pm 0.49^{*}$ & $33.20 \pm 1.13^{*}$ \\
\hline & $S$ & $17.00 \pm 4.24$ & $18.05 \pm 2.90$ & $16.75 \pm 3.18$ & $17.35 \pm 0.92$ \\
\hline & G2/M & $36.50 \pm 0.71$ & $34.50 \pm 0.71$ & $16.90 \pm 1.27^{*}$ & $22.40 \pm 1.98^{*}$ \\
\hline \multirow[t]{3}{*}{ A549 } & G0/G1 & $55.64 \pm 0.28$ & $57.84 \pm 0.77$ & $56.34 \pm 0.14$ & $58.82 \pm 0.33^{*}$ \\
\hline & $s$ & $14.85 \pm 0.05$ & $13.99 \pm 0.16$ & $14.32 \pm 0.23$ & $13.43 \pm 0.45$ \\
\hline & G2/M & $31.01 \pm 0.28$ & $29.58 \pm 0.73$ & $30.82 \pm 0.02$ & $28.86 \pm 0.81$ \\
\hline \multirow[t]{3}{*}{ DU145 } & G0/G1 & $47.73 \pm 2.21$ & $48.49 \pm 0.81$ & $46.46 \pm 4.21$ & $56.14 \pm 1.33^{*}$ \\
\hline & $S$ & $13.52 \pm 1.12$ & $12.46 \pm 0.44$ & $11.47 \pm 1.27$ & $9.10 \pm 0.76$ \\
\hline & G2/M & $36.76 \pm 0.76$ & $36.24 \pm 0.35$ & $36.14 \pm 1.61$ & $31.20 \pm 0.54^{*}$ \\
\hline \multirow[t]{3}{*}{ HepG2 } & G0/G1 & $28.70 \pm 2.40$ & $29.75 \pm 0.35$ & $25.20 \pm 2.55$ & $28.45 \pm 0.78$ \\
\hline & $S$ & $17.80 \pm 2.55$ & $16.85 \pm 0.21$ & $16.20 \pm 1.70$ & $16.20 \pm 1.13$ \\
\hline & G2/M & $27.95 \pm 1.34$ & $26.82 \pm 0.99$ & $25.30 \pm 4.53$ & $25.70 \pm 1.84$ \\
\hline \multirow[t]{3}{*}{ Hela } & G0/G1 & $62.42 \pm 0.31$ & $62.48 \pm 0.08$ & $63.49 \pm 1.33$ & $63.59 \pm 2.26$ \\
\hline & $S$ & $10.35 \pm 0.28$ & $9.02 \pm 0.59$ & $8.19 \pm 0.24$ & $7.86 \pm 0.33$ \\
\hline & G2/M & $25.87 \pm 0.27$ & $26.36 \pm 0.28$ & $24.90 \pm 0.32$ & $26.19 \pm 0.12$ \\
\hline \multirow[t]{3}{*}{ Hep2 } & G0/G1 & $64.80 \pm 0.25$ & $67.02 \pm 0.54$ & $66.98 \pm 0.00$ & $63.97 \pm 0.50$ \\
\hline & $S$ & $6.83 \pm 0.05$ & $6.75 \pm 0.38$ & $7.31 \pm 0.08$ & $7.48 \pm 0.72$ \\
\hline & G2/M & $28.56 \pm 0.20$ & $26.45 \pm 0.66$ & $26.98 \pm 1.28$ & $28.99 \pm 0.16$ \\
\hline
\end{tabular}

Results are expressed as the percentage of total cells. Data represent mean \pm SD values of triplicate experiments. Tukey-Kramer Multiple Comparison test; ${ }^{*} p<0.05 ;{ }^{* *} p<0.01$

( $p>0.05)$. The other cell lines showed no significant difference when compared to untreated cells $(\mathrm{p}>0.05)$ (Figure 3A).

To confirm the apoptosis-inducing effect of lycopene on cancer cell lines, we stained cells with DAPI. In contrast to control cells, which had very little condensed or fragmented chromatin, the majority of lycopene-treated cells displayed apoptotic features, including condensed nuclei, membrane blebbing, and nuclear fragmentation (Figure 3B and 3C).

\section{Discussion}

The present study provided several sets of information on the inhibitory effect of lycopene on viability and on cell cycle arrest in eight different cancer cell lines.

Lycopene is highly hydrophobic, turning its administration in aqueous cell culture media difficult. Vehicles such as THF, DMSO, or lipid micelles have been proposed, and most studies use THF as the solvent [20-22], which can be toxic to some cell lines (including prostate cell lines), limiting the concentrations of lycopene. We used $10 \%$ water-soluble lycopene throughout this study, which gave satisfactory and reproducible results.
Several analyses on lycopene effect on cell proliferation used doses higher than the physiological range, which may not be observed in human blood or tissues. $[2,17,22-24]$. Our samples were treated with lycopene within the lower range of other investigations, which had already been detected in human serum $[25,26]$.

Most studies reported the concentration of lycopene in the cell medium and did not monitor the cellular uptake of lycopene, which could be highly variable among cell lines. None of the cells types studied here is specialized in storage of lipophilic compounds including carotenoids, such as hepatic stellate cells previously studied by our group [19]. In this model, uptake of lycopene showed two phases. The first one ranged from 12 to more than $48 \mathrm{~h}$, in which the initial low uptake level was maintained and was equilibrated with the output. Once the fat-storing phenotype was fully induced, the quantity of the stored lycopene increases abruptly, and a high quantity of lycopene was retained within these cells. We understand that this represents synthesis of new transporters or enzymes required for processing and storage of lycopene in this cell type. In the present study, lycopene was internalized early, but remained at low levels 
Table 2 Effect of lycopene (1-5 $\mu \mathrm{M}$ ) on cell cycle progression in different human cancer cell lines after 96 hours

\begin{tabular}{|c|c|c|c|c|c|}
\hline Cell Lines & Cell Cycle phase & CT & $1 \mu \mathrm{M}$ & $3 \mu \mathrm{M}$ & $5 \mu \mathrm{M}$ \\
\hline \multirow[t]{3}{*}{ HT-29 } & G0/G1 & $77.14 \pm 0.02$ & $84.37 \pm 0.10^{*}$ & $40.29 \pm 5.40^{* *}$ & $46.07 \pm 0.68^{* *}$ \\
\hline & $S$ & $8.31 \pm 0.45$ & $4.40 \pm 1.06$ & $19.59 \pm 4.02^{*}$ & $9.30 \pm 0.47$ \\
\hline & G2/M & $13.41 \pm 0.70$ & $10.17 \pm 0.32^{*}$ & $34.72 \pm 0.86^{* *}$ & $40.03 \pm 0.38^{* *}$ \\
\hline \multirow[t]{3}{*}{ T84 } & G0/G1 & $28.14 \pm 0.01$ & $41.84 \pm 1.53^{* *}$ & $32.97 \pm 0.28^{* *}$ & $36.06 \pm 0.06^{* *}$ \\
\hline & $s$ & $17.86 \pm 1.03$ & $17.52 \pm 0.05$ & $18.85 \pm 0.20$ & $19.39 \pm 3.93$ \\
\hline & G2/M & $43.67 \pm 0.01$ & $38.51 \pm 1.48^{*}$ & $45.64 \pm 0.51$ & $50.23 \pm 0.01^{*}$ \\
\hline \multirow[t]{3}{*}{ MCF-7 } & G0/G1 & $17.10 \pm 1.56$ & $22.45 \pm 0.78^{*}$ & $19.30 \pm 0.99^{*}$ & $20.20 \pm 1.13^{*}$ \\
\hline & $S$ & $26.25 \pm 0.35$ & $26.95 \pm 0.07$ & $24.15 \pm 1.20$ & $22.95 \pm 1.48$ \\
\hline & G2/M & $40.50 \pm 0.71$ & $33.85 \pm 1.20^{*}$ & $30.20 \pm 0.28^{*}$ & $24.95 \pm 0.07^{* *}$ \\
\hline \multirow[t]{3}{*}{ A549 } & $\mathrm{G} 0 / \mathrm{G} 1$ & $65.82 \pm 2.62$ & $63.48 \pm 4.47$ & $66.62 \pm 3.59$ & $61.54 \pm 1.14$ \\
\hline & $s$ & $14.10 \pm 3.29$ & $13.61 \pm 2.64$ & $11.55 \pm 2.67$ & $14.90 \pm 0.36$ \\
\hline & $\mathrm{G} 2 / \mathrm{M}$ & $21.31 \pm 0.83$ & $24.56 \pm 2.21^{*}$ & $23.40 \pm 1.41^{*}$ & $25.18 \pm 0.73^{*}$ \\
\hline \multirow[t]{3}{*}{ DU145 } & G0/G1 & $56.24 \pm 7.90$ & $46.12 \pm 15.97$ & $25.99 \pm 7.43^{* *}$ & $16.76 \pm 1.61^{* *}$ \\
\hline & $S$ & $12.19 \pm 3.79$ & $16.36 \pm 3.25$ & $8.02 \pm 2.14$ & $8.57 \pm 1.70$ \\
\hline & G2/M & $29.89 \pm 3.99$ & $31.26 \pm 5.85$ & $56.97 \pm 6.24^{* *}$ & $55.93 \pm 5.53^{* *}$ \\
\hline \multirow[t]{3}{*}{ HepG2 } & G0/G1 & $59.68 \pm 0.09$ & $47.17 \pm 4.18^{*}$ & $23.23 \pm 0.59^{* *}$ & $19.91 \pm 5.82^{* *}$ \\
\hline & $s$ & $12.33 \pm 0.86$ & $10.68 \pm 2.74$ & $7.04 \pm 0.52^{*}$ & $7.91 \pm 2.71$ \\
\hline & G2/M & $26.39 \pm 0.41$ & $36.63 \pm 7.25^{*}$ & $57.84 \pm 1.53^{* *}$ & $59.49 \pm 7.52^{* *}$ \\
\hline \multirow[t]{3}{*}{ Hela } & G0/G1 & $62.42 \pm 0.01$ & $62.48 \pm 0.08$ & $63.49 \pm 1.33$ & $63.59 \pm 2.26$ \\
\hline & $s$ & $10.35 \pm 0.18$ & $9.02 \pm 0.59$ & $8.19 \pm 0.24$ & $7.86 \pm 0.33$ \\
\hline & G2/M & $25.87 \pm 0.27$ & $26.36 \pm 0.28$ & $24.90 \pm 0.32$ & $26.19 \pm 0.12$ \\
\hline \multirow[t]{3}{*}{ Hep-2 } & G0/G1 & $62.78 \pm 4.35$ & $69.50 \pm 4.65$ & $63.39 \pm 0.07$ & $61.83 \pm 7.97$ \\
\hline & $S$ & $18.73 \pm 2.57$ & $12.72 \pm 3.64$ & $16.79 \pm 0.73$ & $17.77 \pm 5.70$ \\
\hline & G2/M & $20.66 \pm 1.48$ & $18.65 \pm 1.92$ & $20.31 \pm 0.72$ & $20.53 \pm 2.57$ \\
\hline
\end{tabular}

Results are expressed as the percentage of total cells. Data represent mean \pm SD values of triplicate experiments. Tukey-Kramer Multiple Comparison test; ${ }^{*} p<0.05 ;{ }^{* *} p<0.01$

in all cells, similar to the first phase of internalization into the fat storing liver cells.

Colon cells (HT-29 and T84) reached more rapidly higher intracellular concentrations observed in other cells at $48 \mathrm{~h}$. It is to be noted that these two cell lines responded earlier to lycopene, reaching maximal decrease of viability already at $48 \mathrm{~h}$. The other four cell lines that responded to lycopene reached the same level of cell number decrease only after $96 \mathrm{~h}$. Colon cells normally have access to alimentary lycopene, and may be provided by molecular pathways that accelerate lycopene internalization. However, the fact that other cell types that are sensitive to lycopene reached the same inhibition levels after $48 \mathrm{~h}$ indicated that the lycopene uptake rate is apparently not limiting for its anticancer activity, provided the equilibrium with lycopene present in the external environment. This suggests that maintaining the equilibrium of lycopene input and output may be relevant for its effect on cancer, recommending a permanent minimal supply of alimentary lycopene.

In the present study, the cell lines that have active steroid receptors (estrogen or androgen) and are sensitive to this signaling pathway were also sensitive to lycopene-mediated inhibition of cell proliferation. Interference in this pathway that controls cell proliferation in association with retinoid receptor was associated with apoptosis and inhibition of the cell cycle progression $[27,28]$. Furthermore, Liu et al. [29] found that lycopene can be selectively accumulated by androgen-sensitive prostate cells and localized to the nuclear membrane and nuclear matrix, suggesting a possible role for a lycopene on receptor transport.

Many studies in mammary $[14,21]$ and prostate cancer cells [30-32] reported that lycopene is able to act as an antitumor agent by arresting cell proliferation and/or by inducing apoptosis, the action in other organs of its beneficial action is still under debate.

Prostate cancer is the second most common cause of cancer death in American men [33]. Epidemiological evidence indicates that the consumption of tomatoes or tomato-derived alimentary products and the risk of prostate cancer are inversely correlated [34]. Tang et al. [2] found no significant inhibitory or stimulating effect on growth with DU145 cells treated with lycopene at concentrations up to $50 \mu \mathrm{mol} / \mathrm{L}$ for the first $24 \mathrm{~h}$. However, significant inhibition was observed here in DU145 

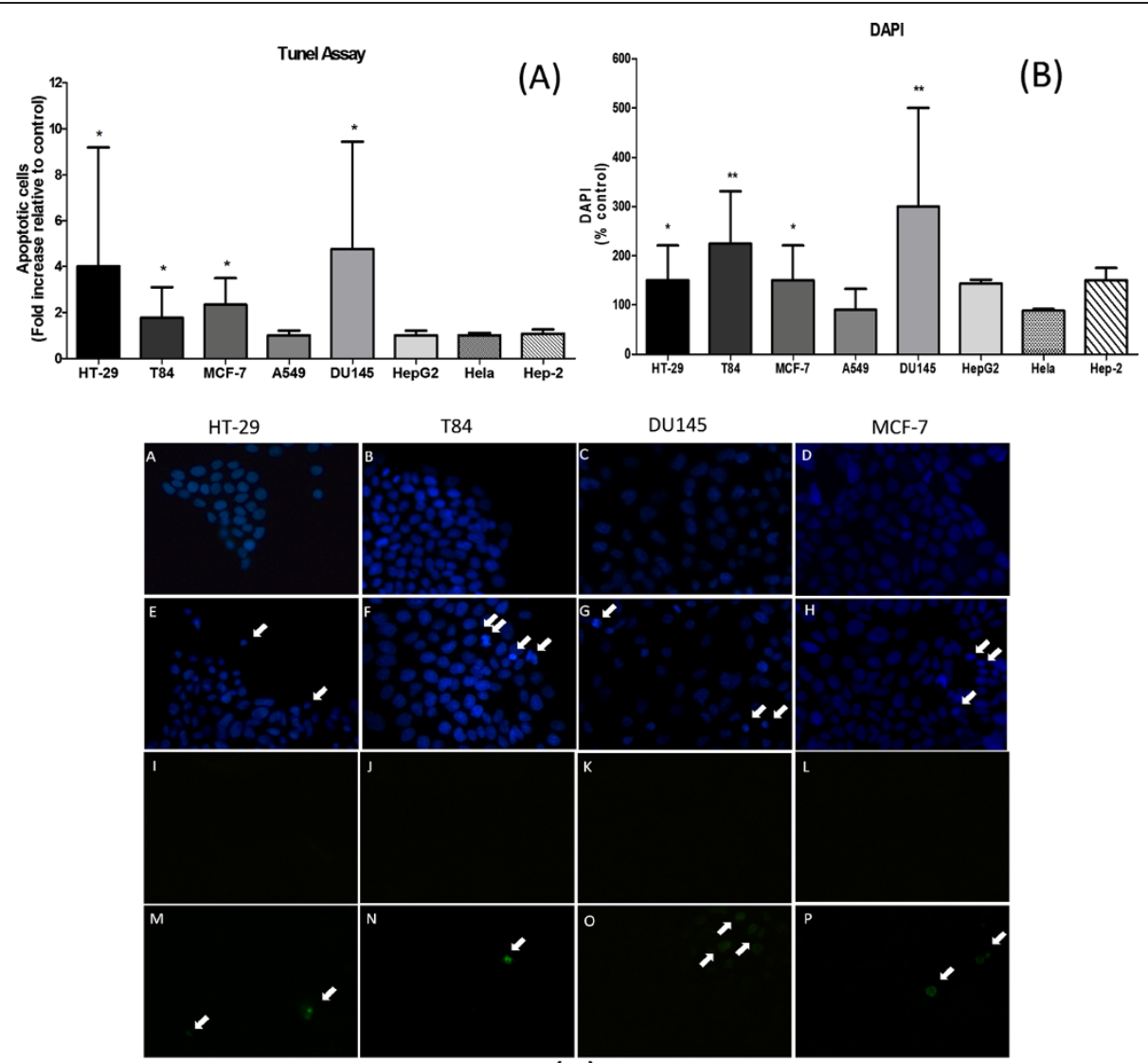

(C)

Figure 3 Apoptosis-inducing activity of lycopene in human cancer cells. (A) Human cancer cells incubated with lycopene (3 $\mu \mathrm{M})$ for $96 \mathrm{~h}$ were analyzed by the TUNEL assay. TUNEL-positive cells were measured by fluorescence microscope. (B) Lycopene-treated human cancer cells were then stained with DAPI (4,'6-diamidino-2-phenylindole) for $3 \mathrm{~min}$. Chromatin condensation was observed using fluorescence microscopy. Arrows in the micrographs indicate areas of chromatin condensation. Percentage of cells undergoing apoptosis was determined by counting apoptotic nuclei of DAPI-stained cells. ND, not detected. Values are means \pm SD $(n=3)$. Bars with asterisks are significantly different from controls ( $p>0.05)$. (C) Detection of apoptotic cells (in green) by TUNEL method in human cancer cells. The cells were treated (M-P) or not (I-L) with lycopene for $48 \mathrm{~h}$. Nuclei were counterstained with DAPI (blue) $(\mathbf{A}-\mathbf{H})$. Chromatin condensation was observed in treated cells $(\mathbf{E}-\mathbf{H})$.

cells treated with lycopene from 48 to $96 \mathrm{~h}$. Lycopene at $>20 \mu \mathrm{mol} / \mathrm{L}$ inhibited DU145 cells at $96 \mathrm{~h}$ as compared with controls. The $50 \%$ inhibitory concentration of lycopene for these cell lines at $96 \mathrm{~h}$ was $26.6 \mu \mathrm{mol} / \mathrm{L}$. These concentrations were not physiological and the present results showed a cell viability reduction of $10 \%$ only after $96 \mathrm{~h}$ with 1,3 and $5 \mu \mathrm{mol}$.

In breast cancer MCF-7 cells lycopene inhibited cell proliferation as monitored by MTT. Lycopene at micromolar concentrations inhibited MCF-7 cell growth in a dose-dependent manner and the minimal inhibiting concentration was $3.5 \mu \mathrm{M}$ by MTT and $5 \mu \mathrm{M}$ by BrdU assays at 48 hours. [23,25] In our study we used similar concentration and MCF-7 decreased proliferation with $1 \mu \mathrm{M}$ of lycopene at $48 \mathrm{~h}$.

Burgues et al. [15] observed no changes in cellular proliferation by cell counting at any concentration between $0.0001-10 \mu \mathrm{M}$ of lycopene for DU145 and A549 cells, and the only cell line that responded to lycopene by cell number reduction was the HepG2 at 1 and $10 \mu \mathrm{M}$ doses after $24 \mathrm{~h}$ of incubation. In our study, HepG2 and A549 lines also decreased its proliferation at 1,3 and $5 \mu \mathrm{M}$, but only after $96 \mathrm{~h}$ of incubation. No changes in cellular proliferation were found by Hep2 and Hela cells.

Previous studies [13,18,35] report that lycopene induced a G1/S cell cycle arrest, which is corroborated by the downregulation of cyclins, including cyclin E [36] and cyclin D1 $[35,37]$ and/or by the upregulation of cyclin A and p27 [36].

Hwang and Bowen [18] demonstrated an interference of lycopene with the cell cycle of LNCaP cells in the G2/ M-phase, although Hantz et al. [22] found that purified lycopene, at concentrations lower than those used in previous studies, did not affect the proliferation but modified the apoptosis in LNCaP cells. In breast and 
colon cancer models, previous studies showed that lycopene promoted cell cycle modification and increased cells in the G0/G1 phase after 24 hours of exposure $[12,35,38]$.

In our study, lycopene was able to promote cell cycle arrest, resulting in an increase of cells in G0/G1 phase or $\mathrm{G} 2 / \mathrm{M}$, depending upon the tumor cell type. Whilst arrest in G0/G1 can be reverted and cells will proceed the proliferation after interruption of the treatment, the G2/M arrest leads potentially to apoptosis [39]. Lycopene-induced association of the two phenomena in HT-29 and DU45 cells may be promising for prostate and adenocarcinoma prevention or treatment.

Increased resistance to apoptosis is a hallmark of many tumor cells. The functional inhibition of specific antiapoptotic factors may provide a rational basis for the development of novel therapeutic strategies. Therefore, apoptosis deficiency is considered to be a major cause of the therapeutic resistance of tumors in the clinic, since many chemo- and radiotherapeutic agents act through the induction of apoptosis. Our results showed a significant increase in apoptosis that followed arrest cell cycle in four cancer cell lines (HT-29, DU145, T84 and MCF7). This may indicate that lycopene could be proposed as adjuvant in cancer chemotherapy.

Other reports demonstrated that lycopene can inhibit the proliferation of cancer cells through the induction of apoptosis in different cell lines [12,30], but only a few studies demonstrated this effect after long period of treatment of lycopene and with low doses $(<5 \mu \mathrm{M})$. Several studies suggest an effect of lycopene in decrease cyclin D1 and phospho-AKT levels and by an increase in p21, p27 and p53 levels and in Bax: Bcl-2 ratio [12].

We demonstrated the capacity of lycopene to inhibit cell proliferation, arrest cell cycle in different phases and increase apoptosis, mainly in breast, colon and prostate cell lines after $96 \mathrm{~h}$. These observations suggest that lycopene may alter cell cycle-regulatory proteins depending on the type of cancer and the dose of lycopene administration. Taken together, these data indicated that the potential anticancer effect of lycopene was cellular type, time and dose-dependent.

\section{Materials and methods Reagents}

All-trans lycopene was purchased from Sigma Chemical Company (St. Louis, MO, USA). Water-soluble (WS) lycopene (10\%) was provided by Roche (Rio de Janeiro, RJ, Brazil). Dulbecco's cell culture medium and bovine serum albumin were obtained from Sigma, and fetal bovine serum (FBS) from Laborclin (Campinas, SP, Brazil). Tissue culture flasks and cell scrapers were obtained from Nunc (Roskilde, Denmark). All the chemicals were of analytical grade.

\section{Cell culture and treatment protocol}

All the cells lines were obtained from the Rio de Janeiro Cell Bank that has certified their identity and quality (Inmetro, Rio de Janeiro, RJ, Brazil). Human prostate cancer cells (DU145), human colon adenocarcinoma cells (HT-29), human cervical cancer cell line (Hela), breast cancer cell line (MCF-7), human liver carcinoma cells (Hep-G2) and human laryngeal carcinoma (Hep-2) cells were plated $25 \mathrm{~cm}^{2}$ tissue culture flasks, $5.0 \times 10^{6}$ cells / flask, and maintained routinely in the Dulbecco's medium supplemented (DMEM) with 10\% fetal bovine serum (FBS) and $2 \mathrm{~g} / \mathrm{L}$ HEPES buffer, $\mathrm{pH} 7.4$, under $5 \%$ $\mathrm{CO}_{2}$ atmosphere. Human colon carcinoma cells (T-84) and human lung adenocarcinoma-derived cells (A549) were maintained in DMEM:HAM-F12 containing 10\% FBS and $100 \mathrm{U} / \mathrm{ml}$ penicillin. Cells were passaged at 70$80 \%$ confluence, about twice a week by trypsinization. For each experiment, all the cells were seeded at $10^{4}$ cell $/ \mathrm{cm}^{2}$ in 6 and 96 multiwell plates for cell cycle and cell proliferation analyses, respectively. After 24 hours, the culture medium was changed and each concentration of lycopene (WS) dissolved in water at $50{ }^{\circ} \mathrm{C}$ within a range from 1 to $5 \mu \mathrm{M}$. The controls were included on each plate. The cells were then incubated for 48 and 96 hours with daily medium replacement [40].

\section{Cell viability assay}

The status of cancer cell lines viability was determined by MTT assay (Amresco, USA). Exponentially growing HSC were adjusted to $1.0 \times 10^{4}$ cells $/ \mathrm{cm}^{2}$ with DMEM, plated in 96-well plates (Corning, USA) at $200 \mu \mathrm{L} /$ well and then incubated for $12 \mathrm{~h}$ according to routine procedure. After being treated with lycopene $(1-5 \mu \mathrm{M})$ and incubated for $48 \mathrm{~h}$ and $96 \mathrm{~h}$ (5 wells for each sample), $20 \mu \mathrm{L} /$ well MTT $(5 \mathrm{~g} / \mathrm{L})$ was added to each well. The medium was then removed after $4 \mathrm{~h}$ incubation and 100 $\mu \mathrm{L} /$ well sodium dodecyl sulfate (SDS) was added to dissolve the reduced formazan product. Finally, the plate was read in an enzyme-linked immunosorbent microplate reader (Bio-Rad 2550, USA) at $490 \mathrm{~nm}$. The cellular proliferation inhibition rate (CPIR) was calculated using the following formula: $\mathrm{CPIR}=(1-$ average A value of experimental group/average A value of control group) $\times 100 \%$.

\section{Cell cycle analysis}

Cells were rinsed briefly with calcium- and magnesiumfree phosphate-buffered saline (PBS) and detached with trypsin at room temperature. After centrifugation, as the cells were washed twice with PBS, $1 \times 10^{6}$ cells were resuspended in $1.0 \mathrm{~mL}$ ice-cold VindeLov solution [41], containing $0.1 \%$ Triton X-100, $0.1 \%$ citrate buffer and $0.1 \mathrm{mg} / \mathrm{ml} \mathrm{RNase}$ and $50 \mu \mathrm{g} / \mathrm{mL}$ propidium iodide (Sigma Chemical Co., St.Louis, MO). After 15 minutes 
incubation, the cell suspension was analyzed for DNA content by flow cytometry using a FACSCalibur flow cytometer (Becton Dickinson, Mountain View, CA). The relative proportions of cells with DNA content diploid G0-G1 (2n), S phase ( $>2 \mathrm{n}$ but $<4 \mathrm{n}$ ), and G2/M phase $(4 n)$ were acquired and analyzed using CellQuest and WinMDI 2.9, respectively. The percentage of cell population at a particular phase was estimated with EXPO32 V1.2 Analysis software. Cell dissociation procedure does not affect fluorescence under the experimental conditions that were used in this study or in any others of which we are aware.

\section{Apoptosis assay (morphological analyses of DAPI-stained cells)}

Human cancer cells lines $\left(1.0 \times 10^{4}\right.$ cells $\left./ \mathrm{cm}^{2}\right)$ were treated with lycopene at a concentration of $3 \mu \mathrm{M}$ in 96-well plates. After $96 \mathrm{~h}$ of incubation, cell death was detected by TdT-mediated dUTP terminal nick-end labeling kit (TUNEL, ApopTag ${ }^{\circledR}$ Plus Fluorescein in Situ Detection Kit, Chemicon Int. Inc, Temecula, CA). Nuclei were counterstained with $1 \mu \mathrm{g} / \mathrm{mL}$ DAPI during $3 \mathrm{~min}$. Slides were examined in a fluorescence microscope (Axiophot, Zeiss) and images were acquired with AxioCam Hrc digital camera. Apoptotic data are reported as percentage apoptosis, obtained by determining the numbers of apoptotic cells versus the total number of cells. For each sample, a minimum of 3 counts involving a minimum of 100-200 cells/count were scored. Apoptotic data are presented as the mean \pm SD for three independently performed experiments.

\section{Statistical analysis}

The presented data are mean values \pm standard error of three independent experiments done in duplicate $(n=6)$. Statistical comparisons were carried out by ANOVA and post hoc Tukey's test using Graph Pad Prism 4.0 and Statistical 6.0 program. The differences were considered significant when $p<0.05$.

\section{Competing interests}

The authors declare that they have no competing interests.

\section{Authors' contributions}

TAJ, OFL, MNB, MGA and BR performed experiments and summarized the data; TTA, MRB and BR designed experiments; TAJ, MRB and BR wrote the paper; all authors have read and approved the final manuscript.

\footnotetext{
Author details

${ }^{1}$ Laboratory of Nutritional Biochemistry, Program of Food and Nutrition, UNIRIO, Rio de Janeiro, Brazil. '2 Laboratory of Cell Proliferation and Differentiation, Institute of Biomedical Sciences, Federal University of Rio de Janeiro, Rio de Janeiro, Brazil. ${ }^{3}$ Excellion Biomedical Services, Petrópolis, Rio de Janeiro, Brazil. ${ }^{4}$ Departamento de Tecnologia de Alimentos, Universidade Federal do Estado do Rio de Janeiro, Escola de Nutrição, CEP 22290-240 Rio de Janeiro, RJ, Brazil.
}

Received: 19 March 2012 Accepted: 24 July 2012

Published: 6 August 2012

\section{References}

1. Dorgan JF, Sowell A, Swanson CA, Potischman N, Miller R, Schussler N, Stephenson HE Jr: Relationship of serum carotenoids, retinal, alphatocopherol and selenium with breast cancer risk:results from a prospective study in Columbia, Missouri (United States). Cancer Causes Control 1998, 9:89-97.

2. Tang $L$, Jin $T$, Zeng $X$, Wang JS: Lycopene inhibits the growth of human androgen-independent prostate cancer cells in vitro and in BALB/c nude mice. J Nutr 2005, 135:287-290.

3. Franceschi S, Bidoli E, La Vecchia C, Talamini R, D'Avanzo B, Negri E: Tomatoes and risk of digestive-tract cancers. Int J Cancer 1994, 59:181-184

4. Erhardt JG, Meisner C, Bode JC, Bode C: Lycopene, beta-carotene, and colorectal adenomas. Am J Clin Nutr 2003, 78:1219-1224.

5. Guttenplan JB, Chen M, Kosinska W, Thompson S, Zhao Z, Cohen LA: Effects of a lycopene-rich diet on spontaneous and benzo(a)pyrene-induced mutagenesis in prostate, colon and lungs of the lacZ mouse. Cancer Lett 2001, 164:1-6.

6. Kucuk O, Sarkar FH, Sakr W, Djuric Z, Pollak MN, Khachik F, Li YW, Banerjee M, Grignon D, Bertram JS: Phase II randomized clinical trial of lycopene supplementation before radical prostatectomy. Cancer Epidemiol Biomarkers Prev 2001, 10(8):861-868.

7. Ansari MS, Gupta NP: Lycopene: A novel drug therapy in hormone refractory metastatic prostate cancer. Urol Oncol 2004, 22(5):415-420.

8. Wertz K, Siler U, Goralczyk R: Lycopene: modes of action to promote prostate health. Arch Biochem Biophys 2004, 430(1):127-134.

9. Kumar NB, Besterman-Dahan K, Kang L, Pow-Sang J, Xu P, Allen K, Riccardi D, Krischer JP: Results of a Randomized Clinical Trial of the Action of Several Doses of Lycopene in Localized Prostate Cancer: Administration Prior to Radical Prostatectomy. Clin Med Urol 2008, 1:1-14.

10. Rao AV: Processed tomato products as a source of dietary lycopene: bioavailability and antioxidant properties. Can J Diet Pract Res 2004, 65:161-165

11. Das S, Otani H, Maulik N, Das DK: Lycopene, tomatoes, and coronary heart disease. Free Radic Res 2005, 39:449-455.

12. Palozza P, Colangelo M, Simone R, Catalano A, Boninsegna A, Lanza P, Monego G, Ranelletti FO: Lycopene induces cell growth inhibition by altering mevalonate pathway and Ras signaling in cancer cell lines. Carcinogenesis 2010, 31(10):1813-1821.

13. Hwang ES, Bowen PE: Cell cycle arrest and induction of apoptosis by lycopene in LNCaP human prostate cancer cells. J Med Food 2004, 7(3):284-289.

14. Karas M, Amir H, Fishman D, et al: Lycopene interferes with cell cycle progression and insulin-like growth factor I signaling in mammary cancer cells. Nutr Cancer 2000, 36(1):101-111.

15. Burgess LC, Rice E, Fischer T, Seekins JR, Burgess TP, Sticka SJ, Klatt K: Lycopene has limited effect on cell proliferation in only two of seven human cell lines (both cancerous and noncancerous) in an in vitro system with doses across the physiological range. Toxicol in Vitro 2008, 22(5):1297-1300.

16. Diehl JA: Cycling to cancer with cyclin D1. Cancer Biol Ther 2003, 1:226-231.

17. Park YO, Hwang ES, Moon TW: The effect of lycopene on cell growth and oxidative DNA damage of Hep3B human hepatoma cells. Biofactors 2005, 23:129-139.

18. Ivanov NI, Cowell SP, Brown P, Rennie PS, Guns ES, Cox ME: Lycopene differentially induces quiescence and apoptosis in androgen-responsive and -independent prostate cancer cell lines. Clin Nutr 2007, 26:252-263.

19. Teodoro AJ, Perrone D, Martucci RB, Borojevic R: Lycopene isomerisation and storage in an in vitro model of murine hepatic stellate cells. Eur J Nutr 2009, 48:261-268.

20. Hantz HL, Young LF, Martin KR: Physiologically attainable concentrations of lycopene induce mitochondrial apoptosis in LNCaP human prostate cancer cells. Exp Biol Med 2005, 230:171-179.

21. Prakash P, Russel RM, Krinsky NI: In vitro inhibition of proliferation of estrogendependent and estrogen-independent human breast cancer cells treated with carotenoids or retinoids. Nutr Cancer 2001, 131:1574-1580.

22. Livny O, Kaplan I, Reifen R, Polak-Charcon S, Madar Z: Lycopene inhibits proliferation and enhances gap-junctional communication on KB-1 human oral tumor cells. J Nutr 2002, 132:3754-3759. 
23. Fornelli F, Leone A, Verdesca I, Minervini F, Zacheo G: The influence of lycopene on the proliferation of human breast cell line (MCF-7). Toxicol In Vitro 2007, 21:217-223

24. Salman H, Bergman M, Djaldetti M, Bessler H: Lycopene affects proliferation and apoptosis of four malignant cell lines. Biomed Pharmacother 2007, 61:366-369.

25. Allen CM, Schwartz SJ, Craft NE, Giovannucci EL, De Groff VL, Clinton SK: Changes in plasma and oral mucosal lycopene isomer concentrations in healthy adults consuming standard servings of processed tomato products. Nutr Cancer 2003, 47(1):48-56.

26. Jenab M, Ferrari P, Mazuir M, Tjonneland A, Clavel-Chapelon F, Linseisen J, Trichopoulou A, Tumino R, Bueno-de-Mesquita HB, Lund E, Gonzalez CA, Johansson G, Key TJ, Riboli E: European Prospective Investigation into Cancer and Nutrition (EPIC) study. Variations in lycopene blood levels and tomato consumption across European countries based on the European Prospective Investigation into Cancer and Nutrition (EPIC) study. J Nutr 2005, 135(8):2032S-2036S.

27. Hirsch K, Atzmon A, Danilenko M, Levy J, Sharoni Y: Lycopene and other carotenoids inhibit estrogenic activity of 17 beta-estradiol and genistein in cancer cells. Breast Cancer Res Treat 2007, 104(2):221-230.

28. Galluzzo P, Martini C, Bulzomi P, Leone S, Bolli A, Pallottini V, Marino M: Quercetin-induced apoptotic cascade in cancer cells: antioxidant versus estrogen receptor alpha-dependent mechanisms. Mol Nutr Food Res 2009, 53(6):699-708.

29. Liu A, Pajkovic N, Pang Y, Zhu D, Calamini B, Mesecar AL, van Breemen RB: Absorption and subcellular localization of lycopene in human prostate cancer cells. Mol Cancer Ther 2006, 5:2879-2885.

30. Ford NA, Elsen AC, Zuniga K, Lindshield BL, Erdman JW Jr: Lycopene and Apo-12'-Lycopenal Reduce Cell Proliferation and Alter Cell Cycle Progression in Human Prostate Cancer Cells. Nutr Cancer 2011, 63(2):256-263.

31. Mossine W, Chopra P, Mawhinney TP: Interaction of tomato lycopene and ketosamine against rat prostate tumorigenesis. Cancer Res 2008, 68(11):4384-4391.

32. Yang CM, Yen YT, Huang CS, Hu ML: Growth inhibitory efficacy of lycopene and $\beta$-carotene against androgen-independent prostate tumor cells xenografted in nude mice. Mol Nutr Food Res 2011, 55(4):606-612.

33. Bissell MJ, Le Beyec J, Anderson RL: Prostate Cancer in Bone: Importance of Context for Inhibition of Matrix Metalloproteinases. J Natl Cancer Inst 2002, 94(1):4-5.

34. Ellinger S, Ellinger J, Stehle P: Tomatoes, tomato products and lycopene in the prevention and treatment of prostate cancer: do we have the evidence from intervention studies? Curr Opin Clin Nutr Metab Care 2006, 9(6):722-727.

35. Palozza P, Serini S, Boninsegna A, Bellovini D, Lucarini M, Monastra G, Gaetani S: The growth-inhibitory effects of tomatoes digested in nitro in colon adenocarcinomacells occur through down-regulation of cyclin D1, $\mathrm{BCl}-2$ and $\mathrm{BCl}-\mathrm{XL}$. Br J Nutr 2007, 98:789-795.

36. Nahum A, Hirsch K, Danilenko M, Watts CK, Prall OW, Levy J, Sharoni Y: Lycopene inhibition of cell cycle progression in breast and endometrial cancer cells is associated with reduction in cyclin D levels and retention of p27(Kip1) in the cyclin E-cdk2 complexes. Oncogene 2001, 20:3428-3436.

37. Tang FY, Shih CJ, Cheng LH, Ho HJ, Chen HJ: Lycopene inhibits growth of human colon cancer cells via suppression of the Akt signaling pathway. Mol Nutr Food Res 2008, 52:646-654.

38. Nahum A, Zeller L, Danilenko M, Prall OW, Watts CK, Sutherland RL, Levy J, Sharoni Y: Lycopene inhibition of IGF-induced cancer cell growth depends on the level of cyclin D1. Eur J Nutr 2006, 45(5):275-282.

39. Rathinasamy K, Jindal B, Asthana J, Singh P, Balaji PV, Panda D: Griseofulvin stabilizes microtubule dynamics, activates p53 and inhibits the proliferation of MCF-7 cells synergistically with vinblastine. BMC Cancer 2010, 9(10):213.
40. Levy J, Bosin E, Feldman B, Giat Y, Miinster A, Danilenko M, Sharoni Y: Lycopene is a more potent inhibitor of human cancer cell proliferation than either alpha-carotene or beta-carotene. Nutr Cancer 1995, 24:257-266.

41. Vindelov LL: Flow microfluorometric analysis of nuclear DNA in cells from solid tumors and cell suspensions. A new method for rapid isolation and straining of nuclei. Virchows Arch B Cell Pathol 1977, 24(3):227-242.

doi:10.1186/1475-2867-12-36

Cite this article as: Teodoro et al:: Effect of lycopene on cell viability and cell cycle progression in human cancer cell lines. Cancer Cell International 2012 12:36.

\section{Submit your next manuscript to BioMed Central and take full advantage of:}

- Convenient online submission

- Thorough peer review

- No space constraints or color figure charges

- Immediate publication on acceptance

- Inclusion in PubMed, CAS, Scopus and Google Scholar

- Research which is freely available for redistribution

Submit your manuscript at www.biomedcentral.com/submit
C Biomed Central 